\title{
Possessive PHRASES AS DEFINITE EXPRESSIONS in Tupí-Guaraní languages: The Role of THE R-MORPHOLOGY
}

\author{
Sintagmas definidos como expressões definidas \\ em línguas da família Tupi-Guarani: o papel da \\ morfologia- $R$
}

\author{
Heloísa Maria Moreira Lima-Salles* \\ Ana Gabriela Gomes Aguiar**
}

\begin{abstract}
RESUMO
O estudo investiga a sintaxe de sintagmas possessivos em línguas da família Tupí-Guaraní, considerando em particular a hipótese de que a chamada morfologia-R(elacional) denota uma descrição definida, induzindo efeito de definitude. Assumindo a Hipótese-DP, argumenta-se que a morfologia- $R$ no nome que denota o possuidor codifica lexicalmente o núcleo $\mathrm{D}$, por meio de uma relação de agreement, que licencia o possuidor, e permite incluir as línguas TG no grupo de línguas do tipo $\mathrm{D}$ (eterminante) $\mathrm{G}$ (enitivo), em oposição às línguas do tipo A(djetivo) G(enitivo).
\end{abstract}

Palavras-chave: possessivo; concordância; definitude.

\footnotetext{
ABSTRACT

The study investigates the syntax of possessive phrases in Tupí-Guaraní languages, considering the hypothesis that the so-called R-morphology gives rise to a definite description

* UnB - Universidade de Brasília.

** INEP/MEC - Ministério da Educação.
} 
inducing a referential/ definite effect. Assuming the DP Hypothesis, we argue that the R-morphology is a lexical marker of the D head, through an agreement relation licensing the possessor argument, which allows to include TG languages in $D$ (eterminer) $G$ (enitive) language type, as opposed to the A(djective) $\mathrm{G}$ (enitive) language type.

Keywords: possessive phrases; agreement; definite effect.

\section{Possessive phrases in TG Languages}

The study investigates the syntax of possessive phrases in Tupí-Guaraní languages (henceforth TG languages), from the Tupí stock. ${ }^{1}$ We assume with the Tupinist tradition that an inflectional prefix is attached to the noun interpreted as the possessee, encoding the syntactic/ argument relation with the possessor phrase. Descriptively, this prefix, which is referred to as the R(elational)-morphology, determines the status of the possessor phrase with respect to whether it is lexically realized within the noun phrase by a full noun phrase (R1) (cf. 1) or not, the latter implying either (i) a deictic/ an anaphoric interpretation (R2) (cf. 2); or (ii) a generic/ an indefinite interpretation (cf. 3) (R4) (cf. RODRIGUES 1996, 2001; SEKI 2000; CABRAL 2001; CABRAL; COSTA, 2004; GRANNIER 2002; MAGALHÃES 2007, among many others). ${ }^{2 / 3}$

1 The TG family includes approximately 40 languages, among extinct and currently spoken languages (cf. RODRIGUES, 1986). As noted in Rodrigues (1986, p. 32), a notable fact about TG languages is its dispersion in South America, particularly in the Brazilian territory. A related fact is that "[i]n spite of the enormous geographic dispersion, the languages of the Tupí-Guaraní family display little cross-linguistic variation" (p. 32, translated from the original in Portuguese). The present study will heavily rely on the latter observation, as the descriptive patterns will be empirically supported by crosslinguistic data. In this respect, we expect to answer one of the anonymous reviewer's remarks, which points out that the scope of the article is too wide, in considering all TG languages, thus requiring a refinement with the respect to the languages that will be addressed. We are aware that the present discussion takes into consideration a restricted number of languages, mostly Kamaiurá and Guajá languages, and incidentally other TG languages, as found in the quoted literature. However, there is a clear agreement in the Tupinian literature with respect to the occurrence of person marking in dependent predicates through a specific set of prefixes, which includes the so-called R-morphemes (cf. RODRIGUES 1953, and subsequent analyses based on this work). For a typological approach on the syntax of anaphoric person markers, we refer the reader to Jensen (1998).

2 The nouns realizing the possessee in (1)-(3) belong to Class II. Class II includes nouns that begin with a vowel - as opposed to class I, in which the nouns mostly begin with consonants (cf. MAGALHÃES, 2007). This contrast determines a vowel harmony phenomenon, which affects the distribution of the $\mathrm{R}$ morphology alomorphy (cf. also SEKI, 2000, for the Kamaiurá language). We shall not go into the details of the allomorphic patterns.

3 As can be inferred from the examples (1)-(3), the R3 type is not displayed. The R3 morpheme is attached to the noun whenever the possessor argument is null and coreferential with the clausal subject. The Guajá language does not display a dedicated morpheme for encoding this property. The above-mentioned patterns should be sufficient for present purposes. 


\begin{tabular}{|c|c|}
\hline $\begin{array}{c}\text { (1) a. há }=\text { r-ipa- } \varnothing \\
1 \quad \text { R1-house-N } \\
\text { 'my house' }\end{array}$ & Guajá \\
\hline \multicolumn{2}{|c|}{ (MAGALHÃES, 2007, p. 131, example 477a; our translation to English) } \\
\hline $\begin{array}{l}\text { b. Awaré r-ipá r-aké (...) } \\
\text { Awaré R1-house R1-near } \\
\text { 'near the house of the Auré' }\end{array}$ & Guajá \\
\hline
\end{tabular}

\begin{tabular}{|l|l|}
\hline $\begin{array}{l}\text { (2) ha-jpa- } \varnothing \\
\text { R2-house-N } \\
\text { 'his/her house' }\end{array}$ & Guajá \\
\hline (MAGALHÃES, 2007, p. 131, example 477b, our translation to English) \\
\hline
\end{tabular}

\begin{tabular}{|c|c|}
\hline $\begin{array}{l}\text { (3) } t \text {-ipa-ø } \\
\text { R4-house-N } \\
\text { 'house of somone' }\end{array}$ & Guajá \\
\hline \multicolumn{2}{|c|}{ (MAGALHÃES, 2007, p. 131, example 477c, our translation to English) } \\
\hline
\end{tabular}

The absence of the R-prefix gives rise to an attributive interpretation (on the modifier), as contrastively illustrated in (4) and (5) (which is expressed in the English translation through the contrastive use of the definite article in the possessor phrase):

4 Throughout the paper, the notation $\mathrm{N}$ glosses the status of the noun as an argument of the predicate (as opposed to a predicative status); the notation '=' glosses cliticization, while '-' glosses affixation. According to Magalhães (2007, p. 141), in Guajá, the N morphology is expressed by the allomorphs $-\mathrm{a} \sim \emptyset$, the latter occurring with bases ending with central low vowels (nasal and oral), and the former with bases ending with consonants and other vowels. Other notations are used in the examples below, depending on the theoretical approach of the data, namely REFER (for 'referential'), ARG (for 'argument'), owing to role of the nouns as an argument (as opposed to predicate). Accordingly, it is possible to unify the notation in terms of the above-mentioned contrast (argument vs predicate). 


\begin{tabular}{|l|l|}
\hline $\begin{array}{l}\text { Tapirapé } \\
\text { (4) a. marare-a'a- } \varnothing \\
\text { 'cow meat' }\end{array}$ & $\begin{array}{r}\text { b. marare- } \varnothing \text { r-a'a- } \varnothing \\
\text { cow-REFER R-meat-REFER } \\
\text { '(the) meat of the cow' }\end{array}$ \\
\hline (PRAÇA, 2007, p. 74, our translation to English) \\
\hline
\end{tabular}

\begin{tabular}{|l|l|}
\hline $\begin{array}{l}\text { Kajabí } \\
\text { (5) a. tayaupy'a } \\
\begin{array}{l}\text { (wild) pork-liver-ARG } \\
\text { 'pork liver' }\end{array}\end{array}$ & $\begin{array}{l}\text { b. tajaú-a i-py'á- } \varnothing \\
\text { (wild) pork-ARG R-liver-ARG } \\
\text { 'the liver of the pork' }\end{array}$ \\
\hline (DOBSON, 1997, p. 66, our translation to English) \\
\hline
\end{tabular}

We take the contrastive interpretation in $(4 a / 5 a)$ and $(4 b / 5 b)$ to indicate that the R-morpheme is a lexical marker of definiteness in possessive phrases, further implying referentiality. ${ }^{5}$ In particular, we would like to propose that the presence of the R-morphology gives rise to a definite description, an idea that is originally put forward in previous work (AGUIAR, 2013; AGUIAR; SALLES, 2014). We adopt Lyon's (1999) approach, according to which the grammatical encoding of definiteness/ referentiality within the noun phrase implies that the $\mathrm{D}$ category is projected. We further propose that that the R-morpheme on the noun denoting the possessee lexicalizes the $\mathrm{D}$ head.

In the investigation of the structure of the noun phrase in TG languages, we take into consideration Bošković's (2008) analysis, in which languages with and without articles are distinguished in terms of the presence and absence of the DP projection above the NP, respectively. Adapting and applying the relevant tests, we tentatively advance the hypothesis that TG languages project a DP. The conclusion is that the R-morpheme as a possession marker in TG languages is a grammatical device for encoding definiteness/ referentiality, further implying that these languages should be included in the $\mathrm{D}$ (eterminer)- $\mathrm{G}$ (enitive) language group, as opposed to the A(djectival)-G(enitive) language pattern, as proposed in Lyons (1999) and other authors.

The discussion will be developed as follows: in section 2, we shall provide more details on the syntax of R-morphemes, showing that they are

5 Although we do not want to assume a conceptual identity between definiteness and referentiality, we would like to refer to both concepts simultaneously, particularly due to the contrastive effects that are obtained through the absence vs of presence the R-morpheme, as illustrated in (4a/5a) and (4b/5b), respectively. Owing to the complex import of each concept, we will assume Lyons' (1999) approach to their shared properties, as presented below. 
found not only within the noun phrase, but also as inflectional prefixes on verbs and postpositions. In section 3 , we shall present a descriptive approach to the structure of noun phrases in TG languages, which will be followed by a brief exposition of the tenets of Lyons' (1999) theory of definiteness, to be integrated with the proposals concerning the DP Hypothesis, as formulated in Abney (1987), and Longobardi (1994). In section 4, we will apply Bošković's (2008) tests for distinguishing DP and NP languages. It will be shown that TG languages qualify as DP languages (although we will have nothing to say about the hypothesis concerning the contrast with NP languages, a matter that goes beyond the scope of the present discussion). In section 5 , we will provide the final remarks.

\section{MORE ON R-MORPHEMES}

As widely shown in the Tupinist literature, the R-morpheme is found not only within the noun phrase, but also with verbs (under person hierarchy), descriptive predicates and postpositions, as illustrated below, with data from Kamaiurá.

(6) kunu'um-a je=r-etsak

Kamayurá

Boy-N $1 \mathrm{sg}=\mathrm{R}$-see

'the boy saw me'

(SEKI, 2000, p. 155, example 460, our translation to English)

\begin{tabular}{|l|l|}
\hline $\begin{array}{l}\text { (7) ene } \quad \text { ne=r-oryp } \\
\text { you } 2 \mathrm{sg}=\mathrm{R} \text {-happy } \\
\text { 'you are happy' }\end{array}$ & Kamayurá \\
\hline (SEKI, 2000, p. 157, example 472, our translation to English) & \\
\hline
\end{tabular}

(8) a. motaw-a r-ehe

food-N R-for

'for/because of food'

b. h-ehe

3 -for

'because of him'

(SEKI, 2000, p. 71-72, examples 63-65, respectively, our translation to English)

The wide distribution of the R-morpheme suggests that its properties go beyond encoding referentiality/ definiteness on the noun phrase, although it is possible to unify its role as a marker of referentiality in all 
contexts. This is what is proposed in Carvalho (2007) (see also footnote 7). Consequently, a correlation could be drawn between the $\mathrm{D}$ head in the nominal domain and a functional head in the verbal/ postpositional domain licensing the internal argument. In minimalist terms, following Chomsky (1995) (and subsequent work), this head could be ' $\mathrm{V}$ ', above the VP projection, assuming an operation in which the external argument is syntactically absent, under person hierarchy. ${ }^{6}$ As for the PP domain, a functional ' $p$ ' with similar properties should be at stake (the layered PP being motivated by inflected prepositions, as found in Celtic languages (cf. SALLES, 1997)). Under this view, the R-morphology may be analyzed as an (internal) argument marker, within the verbal, the postpositional, and the nominal domain (cf. also GRANNIER, 2005; QUEIXALÓS, 2006).

Coming back to the nominal domain, recall that the R-morphology encodes the predicative relation between a head and its (internal) argument, further determining whether the relevant argument is lexically realized within the syntactic domain of the predicate, or not. A crucial property of the R-morphology is that it provides the means to contrastively distinguish a possessor that is interpreted as definite or indefinite/ arbitrary, as widely noted in the Tupinist tradition. In addition to this, as noted in Seki (2000, p. 58), the R-prefix encoding indefinite interpretation may also occur as a 'citing' device, assigning a generic denotation to the noun (cf. (9a-c), as opposed to $\left.\left(9 \mathrm{a}^{\prime}-\mathrm{c}^{\prime}\right)\right)$, which in some cases gives rise to a slight different meaning (cf. (9a), as opposed to (9a')):

(9) Kamaiurá
a. t-ekowe 'life'
b. t-eayru 'glasses'
c. mijat 'animal/ prey'

A related property is that the possessor argument which is interpreted as indefinite/ arbitrary is necessarily marked as [+Human] (Cf. RODRIGUES, 1994; MAGALHÃES, 2007, p. 129). Interestingly, this property may be compared to the $3^{\text {rd }}$ person plural pronoun/ verbal inflection without an antecedent in languages such as Portuguese, Spanish and English (cf.

6 We are grateful to an anonymous reviewer for pointing the need for a more detailed discussion on the role of the ' $\mathrm{v}$ ' as the corresponding functional head to $\mathrm{D}$, in the extended projection of VP. Although we are not directly concerned with the R-morphology in the VP domain, the idea is that under person hierarchy, 1st and 2nd person internal argument, as opposed to 3rd person, is syntactically encoded through the R-morphology on the verb. Accordingly, the external argument (EA) is not syntactically expressed on the verb, the ' $v$ ' head being available for hosting the R-morphology, as suggested (following CHOMSKY, 1999, we distinguish *v, which projects the EA, and v). 
SUÑER, 1983), which is analyzed as imposing a [+Human] interpretation as well, regardless of the selectional properties of the predicate, as illustrated in (11), with data from Spanish: ${ }^{7}$

(10) Te van a ver

(They=people) are going to see you.

Another general property of arguments receiving an arbitrary interpretation in these languages is that the formal feature plural does not imply plural denotation, as the existential reading may refer to a single entity, as in Bateram na porta: era o carteiro ([Someone] knocked the door: it was the mail man). This is an interesting result, allowing a parallel with the R-morphology in TG languages, as it is not marked for number.

We take the fact that the R-morphology contrastively encodes definite and indefinite interpretation to support the hypothesis that it is a lexical expression of the $\mathrm{D}$ head. The properties of $\mathrm{D}$ have been discussed in the literature within the so-called DP Hypothesis. In the following section we will address the DP hypothesis in connection with TG languages.

\section{The structure of the genitive Phrase in Tupí-Guaraní languages AND THE DP HYPOTHESIS}

\subsection{The STRUcture of THE NOUn PHRASE In Tupí-Guaraní LANGuages}

As widely pointed out in the Tupinist tradition, the noun phrase in TG languages occurs with modifiers and demonstrative determiners either as subject, object or complement of a postposition (cf. SEKI, 2000). In (11a), the noun phrase occurs both in subject and object position, while in (11b), it is found as a complement of a postposition.

\begin{tabular}{|l|l|}
\hline $\begin{array}{l}\text { (11) a. }[x \tilde{a} w \tilde{a} r-a] \quad n=a-o^{\prime} o-j \quad[\text { konomi- } \varnothing] \\
\text { dog-N Neg=3-bite-Neg boy-N } \\
\text { 'The dog did not bite the boy.' }\end{array}$ & Tapirapé \\
\hline
\end{tabular}

(PRAÇA, 2007, p. 91, our translation to English)

7 In languages in which the subject can be null, such as Spanish, the indefinite interpretation does not arise with the lexical pronoun. 


\begin{tabular}{|c|l|}
\hline $\begin{array}{l}\text { b. [toryw-a r-ehe] e-moneta } \\
\text { party-N R1-sobre 2-tell.Imper. } \\
\text { 'Tell [me] about the party.' }\end{array}$ & Kamaiura \\
& \\
\hline (SEKI, 2000, p. 75, our translation to English) & \\
\hline
\end{tabular}

Among Tupinists, regarding the structure of the noun phrase, a rather known property is the distinction between nouns that may be possessed and nouns that may not be, which crucially amounts to the distribution of the R-morphology, as the former displays it, but not the latter. Nouns denoting natural phenomena and entities with fixed reference, such as 'the sun', 'the rain', 'the forest', are not found with the R-morphology. Accordingly, their reference is calculated through uniqueness, familiarity (cf. LYONS, 1999), as in (12a). In (12b), the noun 'kahá' (hammock) does not bear the R-morphology, and is assigned a generic interpretation (through a compositional calculus with the predicate, which is stative and denotes a habitual state of affairs):

(12) a. amýn-a ha=ø-ma-ta'amuhũ

rain-N $\quad 1=\mathrm{R} 1$-CAUS-wet

Guajá

'The rain has wet me.'

(MAGALHÃES, 2007, p. 204, our translation to English)

\begin{tabular}{|l|l|}
\hline b. awá-wahý-ury-hú-a kahá ni=Ø-japó-kwá-j & Guajá \\
Guajá-woman-new-Ints-N hammock Neg=R1-CAUS-fazer- & \\
-saber-Neg \\
'A very young Guajá woman does not know how to make a \\
hammock.' \\
\hline (MAGALHÃES, 2007, p. 157, example 567b, our translation to English) \\
\hline
\end{tabular}

Moreover, as is well known, languages may display effects of definiteness through other categories. A referential interpretation/ definite description may be obtained with a demonstrative, as illustrated in (13): ${ }^{8}$

8 Other strategies such as the use of case morphology may be at stake. The discussion of this property goes beyond the scope of this paper, but see Carvalho (2007) for an analysis relating case, referentiality and the R-morphology. 


\begin{tabular}{|c|c|}
\hline 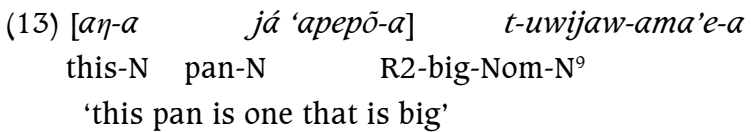 & Kamaiurá \\
\hline 2000 , p. 118 , our translation & \\
\hline
\end{tabular}

As contrastively shown by (12) and (13), while modifiers and the noun receive a single case morphology, as in awá-wahý-ury-hú-a (=Guajá-woman-new-Ints-N), determiners and nouns receive separate case markers, as in $a_{\eta}-a$ já 'apepó-a (=this-N pan-N). We take this to indicate that determiners are projected as an independent syntactic head, while adjective attachment involves adjunction giving rise to a sort of noun composition.

A great deal of research has been done on the syntax of noun phrases and its relation to the grammatical encoding of definiteness and referentiality. As for the possessive phrase we will assume a well-known view that the genitive phrase may be used for identifying a referent in a given universe of reference, this possibility being determined under a crosslinguistic distinction between DG and AG languages languages, in which possessives occur as determiners or adjectives, respectively. In the following section, we shall briefly address these properties and their relation to the so-called DP Hypothesis.

\subsection{Definiteness And the DP Hypothesis}

In a seminal work on the reference of linguistic expressions, John Lyons (1981) points out three types of definite referential expressions: (i) definite noun phrases; (ii) proper nouns; and (iii) personal pronouns. Assuming the tenets of J. Lyons work, Christopher Lyons (1999) develops a well elaborate crosslinguistic approach to definiteness, which is based on the idea that that a 'successful' reference is obtained under the identification of a referent.

In languages bearing articles, a definite article is the syntactic marker of the referent identification in contexts involving notions such as unicity, familiarity, as in A lua está brilhando (=The moon is shining), $O$ carteiro chegou (=The postman arrived), Cheguei atrasada, porque o onibus quebrou (I was late, because the bus broke down). In other situations, the use of the definite article requires an operation identifying the noun, such as a relative clause, or a modification by a prepositional phrase, as in $O$ menino que nasceu é brasileiro (=The boy that was born is Brazilian); $O$ filho de Pedro (=Pedro's son). Differently an indefinite noun phrase may be 
used to denote both a specific entity (a particular entity in the universe of reference), and a non-specific one (an arbitrary member of the class denoted by the noun phrase), as in Comprei um carro (=I bought a car) e Essa pessoa inventou um carro elétrico (=This person invented an electric car), respectively. Accordingly, a definite expression points to the referent of the noun denoted by the noun phrase, contrary to an indefinite expression, which does not allow this identification, although it may denote a specific expression. The definite determiner is thus responsible for expressing the 'identifiable' character of the referent, being lexicalized in configurations involving other categories - distinct from articles - such as demonstrative and possessive pronouns.

According to Lyons (1999), the role of possessives as a definite marker is better described by its ability to be realized in a determiner (Det) position. In particular, this hypothesis relies on the descriptive distinction between the so-called $\mathrm{D}$ (eterminer) $\mathrm{G}$ (enitive) languages and $\mathrm{A}$ (djective) $\mathrm{G}$ (enitive) languages:

in the first type a possessive has the effect of inducing a definite interpretation in the noun phrase it modifies, and a definite article cannot also appear; in the second type a possessive does not have this effect, and the article must co-occur with it to get a definite interpretation (in languages that have an article). (p. 130)

However, mixed languages are also found, Spanish being an example: while the DG pattern occurs with preverbal possessives, the (definite) article being blocked, as in (*la) mi casa, the AG pattern occurs with postverbal possessives, the (definite) article being necessary for encoding definiteness, as in *(la) casa mia, with a difference in form between the prenominal and postnominal possessive (p. 133). In Lyons (1999) analysis, mixed languages are taken as a piece of evidence for adopting the position that possessives are never lexically specified as [+Def], the definiteness of the DG structure being the consequence of the possessive being in Det position rather than the other way around (p. 134). Under this approach, it is possible to draw a correlation between possessors and demonstratives as markers of definiteness, being essentially distinguished by the fact that determiners, but not possessors, are inherently $[+$ Def $] .{ }^{10}$

10 More should be said on the syntax of genitive phrases, particularly in cases in which the possessor is a prepositional phrase/ genitive case marked phrase, not a possessive pronoun. As noted in Lyons (1999, p. 132), in possessive phrases with a full noun phrase possessor, whether prepositional or marked by (genitive) case, as in French and Classical Greek, respectively, a determiner is required for distinguishing a definite and an indefinite reading. In languages without articles, such as Chinese, the reading is ambiguous between definite and indefinite. 
The crucial fact about TG languages is that they do not have articles. A question that arises then is whether it is possible to postulate a $\mathrm{D}$ category in the projection of the noun phrase, in the absence of articles. The hypothesis we would like to advance is that these languages do project a D category. In this respect, we adopt the so-called DP Hypothesis, as originally investigated in Szabolcsi (1983), and Abney (1987), and further developed in Longobardi (1994). Their approach is based on the idea that the structure of the noun phrase should be analyzed as a correlate of the clause structure, due to the similarities in the distribution of noun phrases and clauses. Accordingly, determiners are projected as a D head which takes the noun phrase in its complement position (contrary to previous approaches in which they are analyzed as specifiers of the noun projection (cf. JACKENDOFF, 1977), as illustrated in (14a), under a parallel with the INFL head taking the VP in its complement position, as illustrated in (14b).

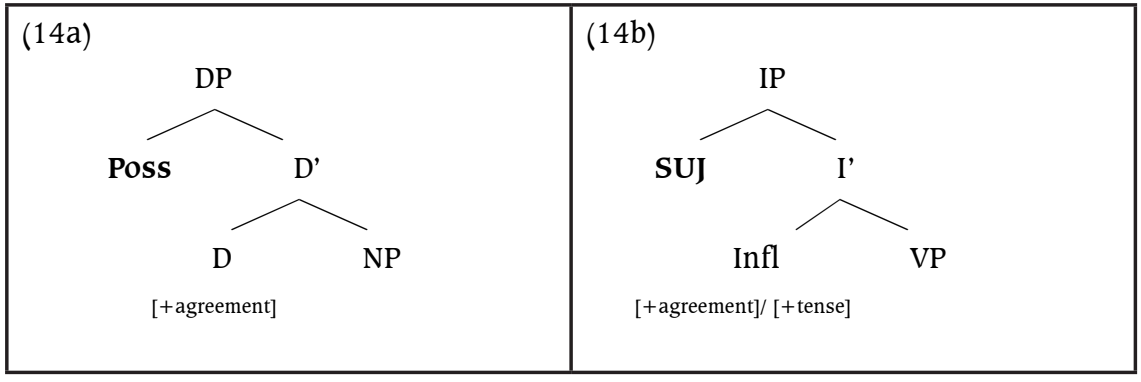

A crucial argument in favour of this analysis is drawn from languages such as Turkish and Hungarian (among others), in which possessive phrases can be shown to parallel with clauses as they display identical grammatical licensing of their (pronominal) arguments. This aspect is also taken into consideration in Lyons' (1999) discussion of the relation between possessives and definiteness. Remarking that Turkish is a null subject language, Lyons (1999) notes that "the verb affixes encoding this subject agreement are, while showing a lot of alomorphy variation, very closely related morphologically to the possessive affixes (...) [although] attached to verbs (and prepositions), these personal suffixes represent the object rather than the subject" (p. 125-126). This is illustrated in (15), with data extracted from Lyons' (1999) work (p. 126).

a. Xarabiyyit-na (car-2PL) 'our car'

b. fihmuu-na (understand+PERF+3PL-2PL) 'they understand us' 
Lyons (1999) points out that possessive affixes in Turkish may be reinforced by a personal genitive pronoun, exactly as nominative pronouns can be used to emphasize a clausal subject affix on the verb, as in siz-in sokağ-iniz (you-GEN street-2PL), extracted from the author (p. 126). Given this, the conclusion is that "possessive affixes are to be analyzed as agreement morphemes" (p. 126), being associated with a pro argument, exactly as the empty subject of null-subject languages is associated with the verb morphology. In the following section these facts will be discussed in relation with the properties of the TG languages.

\subsection{TG LANGUAges AS A DG TyPe LANGUAGE}

Interestingly, TG languages show a similar pattern as compared to Turkish. As we have seen in the previous sections, the distribution of the R-morphology is determined by the lexical vs null realization of the possessor phrase. Moreover, in section 3.1, we have shown that there is a paradigmatic relation between the prefix on the noun denoting the possessee, which is syntactically related to the possessor, on one hand, and the prefix on the (transitive) verb which is syntactically related to the internal ( $3^{\text {rd }}$ person) argument, on the other hand (cf. examples in (1a-b), as opposed to (6)), exactly as in Turkish (although a complex system of person hierarchy in the grammatical encoding of the arguments with transitive verbs is at stake, in TG languages). ${ }^{11}$

We take Lyons' (1999) observations regarding the facts about Turkish (in particular), along with the tenets of the DP Hypothesis, to show that the R-morphology in TG can be assigned an agreement status within the possessive phrase, exactly as person prefixes. Although its forms are not inflected for person, it is possible to show that they form a paradigm (as proposed in CABRAL; RODRIGUES, 2001), given their complementary distribution in their role as argument markers according to the lexical vs null status of the argument (whether a $1^{\text {st }}, 2^{\text {nd }}$ person clitic, or a $3^{\text {rd }}$ person full noun, on one hand, or a $3^{\text {rd }}$ person null argument, on the other hand - that is, the contrastive forms for the lexical and the null argument are restricted to $3^{\text {rd }}$ person).

Following previous work (cf. SALLES 2007; AGUIAR, 2013), we propose that the DP structure in TG languages hosts functional projections between the noun head (No) and the $\mathrm{D}$ head $\left(\mathrm{D}^{\circ}\right)$, which bear the relevant features associated with the grammatical operations within the DP, namely

11 Transitive verbs in TG language display a person hierarchy in the grammatical encoding of the arguments, which is not directly relevant for the present discussion (on this matter, see SEKI, 2000; MONTSERRAT, 1976, cited in SEKI, 2000). 
agreement relations, case marking, as well as argument licensing of the possessor argument. Bearing an agreement feature, the R-morpheme enters a grammatical relation with the D head, licensing the possessor DP in its specifier position. The structure of the DP in TG languages is provided in (16).

$$
\left[D P [ D P _ { \text { possessor } } ] \left[D ^ { \prime } \left[\mathrm { D } \left[_{\text {AgrP }}\left[\text { Agr' R }\left[_{\mathrm{NP} \text { posseessee }} \mathrm{N}\right]\right]\right.\right.\right.\right.
$$

Within this configuration, besides licensing the possessor through the R-morphology, the agreement relation has implications for the referential interpretation of the possessive DP, as illustrated in (1)-(2), as opposed to (3), which in turn contrasts with the absence of the R-morphology, giving rise to a generic reading on the possessor, as illustrated in (4) and (5). Moreover, the generic interpretation may be obtained either with the possessive DP bearing the indefinite R-morpheme (as illustrated in (9)), or with the bare noun, as in (12b), the latter patterning as a non-possessed noun. ${ }^{12}$

Given this, we propose that the R-morphology is the lexical expression of $\mathrm{D}$. Under this view, TG languages may be analyzed as DG type languages. Accordingly, the possessive marker is taken to be a definite marker inducing a definite description.

In the following section, we will take into consideration Bošković's (2008) discussion of the syntax of noun phrases, in which the hypothesis that all natural languages project a DP is challenged. In particular, it is argued that languages differ as to whether the $\mathrm{D}$ category is projected or not. We will tentatively show that TG languages pass the test for postulating the presence of the D category.

\section{BoŠKović $(2005,2008)$ AND THE DP/NP PARAMETER}

The idea that the DP is the universal projection of noun phrases in argument position has been challenged in the literature. In Chierchia (1998; 2003), the so-called Nominal Mapping Parameter is postulated in order to account for the crosslinguistic variation in the interpretation of DP and bare nouns $(=N P)$ in argument vs predicate position under the conjoined application of the features [+/- A(rgument)] and [+/- P(redicate)]. Accordingly, the following patterns arise: (i) $[+\mathrm{A}]$; [-P] languages, such as Chinese; (ii) $[-\mathrm{A}] ;[+\mathrm{P}]$ languages, such as Romance languages; and (iii) $[+\mathrm{A}] ;[+\mathrm{P}]$ lan-

12 It should be noticed that a possession phrase may be assigned a non-referential reading if it is found within a predicate denoting an habitual reading, as in (i), cited in Magalhães (2007, p. 103, example 549), which may be compared to definite generics in languages such as Portuguese:

(i) Awa-wahý-a i-kahá ø-japó-

Awa-woman-N R2-hammock 3-make 'The Awa woman makes her hammock' 
guages, such as Slavic and Germanic languages. We shall not go into the details of how each pattern is empirically supported. However we will look at Bošković's $(2005 ; 2008)$ analyses, which rely on Chierchia's original point.

According to Bošković (2008), the presence of (definite) articles is a typological divide in the crosslinguistic analysis of noun phrases, which can be demonstrated by a number of tests distinguishing languages with a $D$ category realized by a definite article and languages without a D category. As a result, in DP languages, the D head is taken to govern the DP projection, while in NP languages, adjetives, demonstratives, possessives are projected as adjuncts / specifiers. This is illustrated in (17).

$$
\begin{aligned}
& \text { a. }\left[{ }_{\mathrm{DP}} \mathrm{D}^{0}\left[{ }_{\mathrm{DemP}} \operatorname{Dem}^{0}\left[_{\mathrm{Adj}} \operatorname{Adj}^{0}\left[{ }_{\mathrm{NP}} \mathrm{N}^{0}\right]\right]\right]\right]-D P \text { language } \\
& \text { b. }\left[_{\mathrm{NP}}\left[{ }_{\mathrm{DemP}} \operatorname{Dem}^{0}\left[_{\mathrm{AdjP}} \mathrm{Adj}^{0}\right]\right] \mathrm{N}^{0}\right]-N P \text { language }
\end{aligned}
$$

Drawing on Bošković's (2008) generalizations regarding the presence of the D projection, we will show that at least two languages of the TG family languages meet the conditions allowing for a positive marking for this property, although the D category is realized by the R-morphology, not by a (definite) article (as in Indo-European languages).

I. Languages without articles do not allow embedded genitives

- Embedded genitives are found in Guajá

$$
\begin{aligned}
& \text { [[ha=n-imá n-ahý-á]-e } \quad \varnothing \text {-mumu'ũ-á] }-e m-a \\
& 1=\text { R1-animal de criação R1-doença-NZR-RETR R1 - narrar - NZR -N } \\
& \text { 'a narração da doença do meu animal de estimação' } \\
& \text { 2007, p. 28) Guajáalhães, }
\end{aligned}
$$

According to William (2000), quoted by Bošković's (2008), a second genitive is only possible if it is structurally realized in an upper layer of the NP, namely the DP. Conversely, in the absence of the DP layer, the projection of two genitives is blocked, which is confirmed in languages without articles, such as Polish, Russian, Latin.

II. Only languages with a D category allow pronoun doubling

- Pronoun doubling is found in Kaiabi (a TG language)

$$
\begin{aligned}
& \text { [ore-r-a'yra] [ra] ka'ia o-juka } \\
& \text { 1pl-R1-filho ele macaco 3-matar Kaiabí } \\
& \text { 'Nosso filho matou o macaco' (Gomes, 2008, p. 48) }
\end{aligned}
$$

Pronoun doubling is a construction in which an argument is dislocated and a co-referential pronoun doubles it within the predicate. Accor- 
ding to Gomes (2008), in Kaiabí, an argument marked as [+human], may be doubled by a pronoun, regardless of whether it is a subject, an object, the complement of a postposition, or a genitive phrase. Assuming that the dislocated DP raises from a DP projection which is headed by the pronoun, the author argues that phi-features on the pronoun assign the definiteness effect to the whole configuration, as shown in (20) and (21).

Apiaká a’yra

Apiaká son 'Apiaka's son'

Apiaká a’yra wã

Apiaká son he 'Apiaka's son himself'

Other descriptive generalizations are proposed in Bošković's (2008) work. However, not all can be tested for TG languages, given that their typological properties do not entirely parallel with languages bearing canonic (definite) articles (such as Portuguese, Spanish and English). We take the above-mentioned generalizations to be an approximation of the problem of justifying the projection of the D head in TG languages. In this sense, we are aware that more research should be done in order to provide additional crosslinguistic empirical support for the proposed tests. Moreover at this point we do not have anything to say about Bošković's (2008) DP/NP parameter. For present purposes, we tentatively suggest that the DP status of the relevant constructions is independently determined.

\section{Final REMARKS}

This study has addressed the syntax of possessive phrases in TG languages. In the analysis we have investigated the hypothesis that the so-called R-morphology gives rise to a definite description inducing a referential/ definite effect. Assuming the DP Hypothesis, as formulated in Abney (1987) and Longobardi's (1994) analyses, we have argued that the $\mathrm{R}$-morphology is a lexical marker of the D head, through an agreement relation licensing the possessor argument, which allows to include TG languages in $\mathrm{D}$ (eterminer) $\mathrm{G}$ (enitive) language type, as opposed to the $\mathrm{A}$ (djective) $\mathrm{G}$ (enitive) language type.

\section{REFERENCES}

ABNEY, S. The English Noun Phrase and its Sentential Aspect. 234 f. Dissertation (PhD in Linguistics and Philosophy) -MIT, Cambridge, Mass., 1987. Disponível em: <http://www.vinartus.net/spa/87a. pdf > . Acesso em: 20 dez. 2015. 
AGUIAR, A. G. G.Marcação de Definitude em Sintagmas Nominais de Línguas da Família Tupí-Guaraní. 86f. Dissertação (Mestrado em Linguística) - Universidade de Brasília, 2013.

AGUIAR, A. G. G.; SAlLES, H. M. L. Prefixos Relacionais R2 e R4 em construções genitivas e atributivas em línguas Tupí Guaraní. Revista Signótica, n. 26, v. 2, p. 331-352, 2014.

BOŠKOVIĆ, Ž. On the locality of left branch extraction and the structure of NP. Studia Linguistica, n. 59, p. 1-45, 2005.

.What will you have, DP or NP? Proceedings of NELS, n. 37, 2008.

CABRAL, A. S. A. C. Flexão Relacional na família Tupí -Guaraní. Boletim da ABRALIN, Fortaleza, v. 25, p. 233-262, 2001.

CABRAL, A. S. A. C.; COSTA, L. S. da. Xikrín e línguas Tupí-Guaraní: marcas relacionais. In: D'ANGELIS, Wilmar da R. (org.). LIAMES: Anais do II Encontro Macro-Jê). Campinas: Editora Unicamp, 2004. p. 7-19.

CABRAL, A. S. A. C.; RODRIGUES, A. D. (Coord.). Estudos sobre línguas indígenas. Belém: Editora Universitária UFPA, 2001.

CARVALHO, M. G. P. de. Sinais de morte ou vitalidade? Mudanças estruturais da língua Tembé. 120 f. Dissertação (Mestrado) - Centro de Letras e Artes, Universidade Federal do Pará, Belém, 2001.

CARVALHO, F. O. Relational morphemes, argument structure, and morphological explanation. In: CABRAL, A. S. C.; RODRIGUES, A. D. (Orgs.) Linguas e Culturas dos Povos Tupí. Campinas, SP: Curt Nimuendaju, 2007.

CHIERCHIA, G. Reference to Kinds across Languages. Natural Language Semantics, n. 6, 1998, p. 339-405.

CHIERCHIA, G. Semântica. Tradução de Luis Arthur Pagani, Lígia Negri, Rodolfo Ilari. Campinas, SP: Editora da UNICAMP; Londrina, PR: EDUEL, 2003.

CHOMSKY, N. The Minimalist Program. Cambridge/Massachusetts: MIT Press. 1995. . Derivation by Phase. MITWPL 18, 1999.

DOBSON, R. M. Aspectos da Língua Kayabí. Brasília: SIL, 1988. Série Linguística, n. 12.

Gramática prática com exercícios da língua kajabí. Cuiabá: Summer Institute of Linguistics, 1997. Unpublished manuscript.

DOoLEY, R. A. (Red.) Estudos sobre Línguas Tupí no Brasil. Brasília, DF: Summer Institute of Linguistics, 1984

GOMES, N. S. Clíticos, Redobro e Variação na Ordem na Língua Caiabi (Família Tupí-Guaraní). Revista Philologus, ano 14, n. 42. Rio de Janeiro: CiFEFiL, set./dez. 2008.

GRANNIER, D. Aspectos da Morfossintaxe do Guarani Antigo. Tese (Doutorado em Letras e Linguística) - Universidade Federal de Alagoas, Maceió, 2002.

. A natureza dos prefixos relacionais em Guarani Antigo. In: RODRIGUEZ, A.; CABRAL, A. S. A C. (Org.). Novos Estudos sobre Línguas Indigenas. Brasília: Editora UnB, 2005. p.129-140.

GREEN, D. Diferenças entre termos numéricos em algumas línguas indígenas do Brasil. Boletim do Museu Paraense Emílio Goeldi, Série Antropologia, n. 13, v. 2, p. 179-207, 1997. Disponível em: <http://www.sil.org/americas/brasil/SILbpub.html>. Acesso em: $20 \mathrm{dez} .2015$.

JACKENDOFF, R. X-bar Syntax. Cambridge MA: MIT Press, 1977.

JENSEN, C. O desenvolvimento histórico da língua Wayampi. Campinas, Brasil: Editora da Unicamp. 1989. 
The use of coreferential and reflexive markers in Tupí-Guaraní languages. Journal of Amazonian Languages (University of Pittsburgh. Department of Linguistics), v. 1, n. 2, p. 1-49, 1998.

LONGOBARDI, G. Reference and Proper Names: A Theory of N-Movement in Syntax and Logical Form. Linguistic Inquiry, n. 25, v. 4, p.609-665, 1994.

LYONS, C. Definiteness. Cambridge: Cambridge University Press, 1999.

MAGALHÃES, M. M. S. Sobre a Morfologia e a Sintaxe da Língua Guajá. 315 f. Tese (Doutorado em Linguística, Português e Línguas Clássicas) - Instituto de Letras, Universidade de Brasília, Brasília, 2007.

PRAÇA, W. N. Morfossintaxe da Língua Tapirapé. 282 f. Tese (Doutorado em Linguística) -Universidade de Brasília, Brasília, 2007.

QUEIXALÓS. F. The primacy and fate of predicativity in Tupi-Guarani. In: LOIS, X. \& VAPNARSKY, C. (Eds.). Lexical Categories and Root Classes in Ameridian Languages, Bern: Peter Lang International Academic Publishers, 2006.

RODRIGUES, A. D. Morfologia do verbo Tupí. Letras, Curitiba, n. 1, 1953. 1994.

Línguas brasileiras: para o conhecimento das línguas indígenas. São Paulo: Loyola. Argumento e predicado em Tupinambá. Boletim da ABRALIN, n. 19, p. 57-66. 1996. Flexão relacional no tronco linguístico Macro-Jê. Boletim da Associação ABRALIN, Fortaleza, v. 25, p. 219-231. 2001.

SZABOLSCI, A. The possessors that run away from home. The Linguistic Review, n. 3, p. 98$102,1983$.

SALLES, H. M. L. Grammatical encoding of anaphoric relations in Tupí Guaraní languages. In DEAL, A-R. In: CONFERENCE ON THE SEMANTICS OF UNDERREPRESENTED LANGUAGES OF THE AMERICAS, 4., 2007. Proceedings... Massachussets: University of Massachussetts Occasional Papers/UMOP 35, 2007. p. 231-246.

. Prepositions and the Syntax of Complementation. Dissertation (PhD in Linguistics) - University of Wales, 1997.

. Aspectos da sintaxe de pré e posposições em línguas românicas e germânicas. Letras de Hoje, p. 251-265, 2003.

SEKI, L. Gramática do Kamaiurá, Língua Tupi-Guaraní do Alto Xingu. Campinas: Editora da UNICAMP. 2000.

SUÑER, M. Pro ${ }_{\text {arb }}$. Linguistic Inquiry, n. 14, p. 188-191, 1983.

Submetido em: 25/08/2014

Aceito em: 11/05/2015

Revista Letras, Curitiba, n. 92 p. 96-112, JUL/DEZ. 2015.

ISSN 2236-0999 (VERSÃo ELETRÔNICA) 